\title{
Befolkningens holdninger til markedsgørelse af den offentlige sektor \\ Erkendelsesinteresser og forklaringsmodeller i politologien
}

\author{
Andrej Christian Lindholst \\ Adjunkt, Institut for Statskundskab, Aalborg Universitet \\ Morten Balle Hansen \\ Professor MSO, Institut for Statskundskab, Aalborg Universitet
}

På trods af de sidste 30 års bestræbelser på markedsgørelse af den offentlige sektor, gennem inddragelse af private virksomheder, kan specifikke tiltag til stadighed fremkalde stærke holdningsmæssige reaktioner og modstand i befolkningen. I den danske politologi er befolkningens holdninger til markedsgørelse kun undersøgt sporadisk, og et egentligt teoretisk grundlag er ikke udviklet. Denne artikel søger at etablere et teoretisk grundlag i forhold til en mere systematisk forskning ved at give overblik og analysere den internationale politologiske litteratur på området. Vi finder, at den internationale forskning er kendetegnet ved en mindre gruppe af studier, der tilsammen trækker på fire hovedtyper af erkendelsesinteresser (1. demokratiske, 2. politisk-strategiske, 3. transformative og 4. implementeringsmæssige) samt fire typer af forklaringsmodeller (1. erfaring, 2. utilitarisme, 3. ideologi og 4. kultur). Analysen viser også, at forskningen er mangelfuld $\mathrm{i}$ forhold til en balanceret afdækning af forskellige former for markedsgørelse samt forskellige offentlige serviceområder.

Inddragelse af private virksomheder til løsning af offentlige opgaver, eksempelvis i form af privatisering og udlicitering, eller det vi i denne artikel betegner som 'ekstern markedsgørelse', har været en central del af den forvaltningspolitiske dagsorden siden 1980'ernes ledelsesreformer (Ejersbo og Greve, 2014; Hansen, 2011; 2013; Hood, 1991; Højlund, 2004; Pollitt og Bouckaert, 2011). Politologien, der omhandler markedsgørelse, har langt overvejende været baseret på studier af de politiskadministrative rammer, aktører, processer og effekter indenfor udvalgte former for ekstern markedsgørelse. Eksempelvis i forhold til udlicitering, som udgør en af de mest velkendte former og forskningsmæssigt vel belyste former for markedsgørelse, har Andersen (1997) tidligere beskrevet udliciteringens mangeartede strategier, Christensen og Petersen (2010) har analyseret de regulative rammer for udlicitering og offentlige-private partnerskaber, Lindholst og Bogetoft (2011) har afdækket de kontraktstyringsmæssige udfordringer ved implementering af udlicitering, Christensen m.fl. (2012) har gennemgået de forskningsmæssige forklaringer bag beslutninger om udlicitering, mens Hjelmar m. fl. (2013) og Vrangbæk m. fl. (2015) har gennemgået forskningen i udliciteringens effekter på henholdsvis økonomi, servicekvalitet og medarbejdere.

Med denne artikel vil vi gerne fremme en komplementerende forskningsagenda, der etablerer befolkningens holdninger til den eksterne markedsgørelse via inddragelse af private virksomheder, som et selvstændigt forskningsperspektiv i den politologiske forskning. Vi gennemgår den internationale litteratur på området, og vi afdækker de grundlæggende forskningsmæssige erkendelsesinteresser og forklaringsmodeller indenfor forskningsfeltet. Artiklen giver således svar på, hvilke faktorer, der er 
anvendt i den internationale politologiske forskning til at forklare befolkningens opbakning til eller modstand mod den eksterne markedsgørelse, samt hvilke erkendelsesinteresser, der har motiveret denne forskning.

Den forskningsmæssige og samfundsmæssige aktualitet af spørgsmålet om befolkningens holdning til den eksterne markedsgørelse understreges af, at 2010'erne har vist, at eksempelvis privatiseringsprocesser stadig kan fremkalde stærke holdningsmæssige reaktioner og modstand i den danske befolkning og udgør et højspændt og kritisk politisk stridsemne. Det politiske forløb og befolkningens reaktioner henover vinteren 2013/14 ved det delvise salg af aktier i det statsejede selskab DONG Energy til den amerikanske investeringsbank Goldman Sachs, illustrerer aktualiteten med stor tydelighed. Trods en bred indledende politisk konsensus om salget og en finansministers forsikring om, at aktiesalget var sket på baggrund af 'det bedste samlede bud', så viste blandt andet meningsmålinger og offentlige protester en massiv folkelig modstand imod aktiesalget. I forløbet viste to meningsmålinger en modstand i befolkningen på henholdsvis $68 \%$ og $80 \%$, næsten 200.000 danskere underskrev en protest imod salget, politiske forligsparter skiftede holdning, og en regering blev sprængt. ${ }^{1}$

At et privatiseringsforløb i 2010'erne kan frembringe så stærke holdningsmæssige og politiske reaktioner, er overraskende ud fra læsning af den politologiske og forvaltningspolitiske litteratur. Den dominerende fortælling er her, at den eksterne markedsgørelse, da den for alvor blev sat på dagsordenen i 1980'ernes moderniseringsprogrammer, i høj grad mobiliserede konflikter i befolkningen langs den klassiske højre-venstre skala, men fra 1990'erne og frem blev den eksterne markedsgørelse i stigende grad afideologiseret og normaliseret som et politisk-administrativt reformværktøj (Ejersbo og Greve, 2014; Greve, 2000; Greve og Ejersbo, 2005; Hansen, 2011). I forhold til den eksplosive udvikling i sagen om salget af aktier i DONG Energy, så har den eksterne markedsgørelse almindeligvis levet et mere stille og tilbagetrukket liv i forhold til offentlighedens interesse op gennem 2000'erne og frem til midten af 2010'erne. I denne periode er nye former for ekstern markedsgørelse eksempelvis offentlig-private partnerskaber blevet introduceret, og markedsgørelse mere generelt er via forskellige former såsom frit valg og brugerbetaling blevet udbredt til stadigt flere områder i den offentlige sektor.

I den danske politologiske forskning har spørgsmål vedrørende befolkningens holdning til den eksterne markedsgørelse ikke været problematiseret eller søgt forklaret gennem egentlige teoridrevne studier. Kun ganske få studier, eksempelvis af Greve (2000), Grønnegård og Pallesen (2001), Greve og Ejersbo (2005), eller Lecheler m.fl. (2009) berører aspekter, der vedrører befolkningens holdning til den eksterne markedsgørelse - og dette kun indirekte og i forhold til andre forskningsspørgsmål. Empirisk har særligt de fortløbende valgundersøgelser dog afdækket udbredelsen af modstand eller opbakning til udvalgte former for ekstern markedsgørelse (jf. Stubager m.fl., 2013). Modsat forefindes der i den internationale politologiske litteratur en række studier, som tilsammen kan siges at udgøre et forskningsfelt, der på forskellig vis er centreret omkring emnet 'befolkningens holdning til den eksterne markedsgørelse'. I forhold til en dansk politologisk sammenhæng introducerer vi i denne artikel indsigter fra den internationale politologiske litteratur, og vi adresserer to centrale forskningsspørgsmål, der kan bidrage til egentlige forskningsmæssige belysninger af befolkningens holdning til den eksterne markedsgørelse i en dansk sammenhæng. Det første spørgsmål omhandler hvilke erkendelsesinteresser, der anvendes som rationale for forskning i befolkningens holdninger til den eksterne markedsgørelse. Det andet spørgsmål omhandler hvilke forklaringsmodeller, der er udviklet vedrørende befolkningens holdninger til den eksterne markedsgørelse.

Artiklen indeholder følgende afsnit: I første afsnit gennemgår vi metoderne bag afsøgningen og udvælgelsen af studier i vores litteraturgennemgang. I andet afsnit analyserer vi de forskellige erkendelsesinteresser, der forefindes i litteraturen som motivation for studier af befolkningens holdning til den eksterne markedsgørelse. I tredje afsnit analyserer vi de forskellige forklaringsmodeller. I fjerde afsnit diskuterer vi de forskellige problematiseringer og forklaringsmodeller, og vi opstiller en forskningsmæssig ramme i forhold til en sammenfatning af litteraturen samt belysninger i en dansk sammenhæng.

\section{Metode og materialer}

Terminologi

Terminologien omkring det, vi i denne artikel betegner som den 'eksterne markedsgørelse', er ikke entydig i den danske og internationale litteratur. I en stor del af den internationale litteratur anvendes termen 'privatisering' som overlappende med det vi i denne artikel kalder for ekstern markedsgørelse. I en 'bred' forståelse, som er vidt udbredt i den internationale litteratur (Jf. Edlund og Seva, 2013; Hodge, 2000; Lundqvist, 1989; Savas, 2000; Starr, 1988), kan 'privatisering' indkredses som en række politikker og strategier til reorganisering af relationen mellem det offentlige og private, og dette finder sted gennem en formindsket statslig (offentlig) rolle i finansieringen, opgavevaretagelsen og/eller reguleringen af forskellige samfundsmæssige opgaver. I denne brede forståelse bliver 'udlicitering', 'frit valg' eller 'brugerbetaling' til nogle af privatiseringens mange former. Endvidere er termen 
Figur 1. Antal anvendte publikationer om befolkningens holdning til ekstern markedsgørelse i gennemgangen fordelt på publiceringsår i perioden 1983-2012

Antal publikationer per år 1983-2015

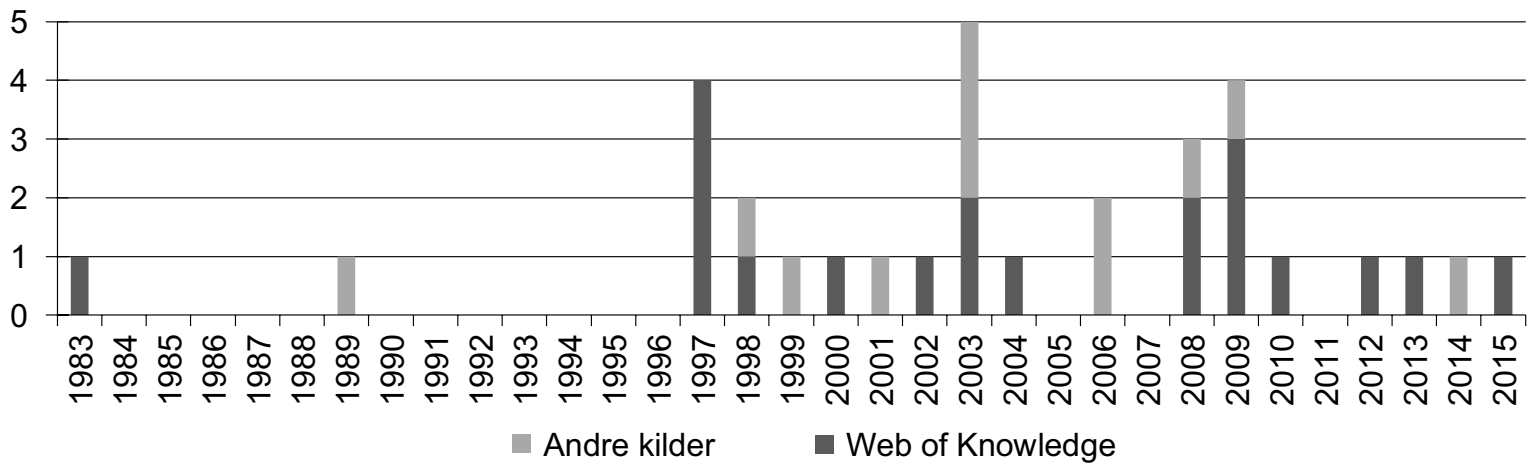

* Figuren angiver publikationer fordelt på år og afsøgningskilder, der er fremfundet gennem kombinationer af søgeordene: 'marketisation/ marketization', 'privatization/privatisation', 'opinion', 'contract', 'choice', 'attitudes', og 'preferences'.

'(offentlig-privat) partnerskab' i dele af den internationale litteratur anvendt synonymt med den brede forståelse af privatisering (Jf. Savas, 2000). I en mere snæver anvendelse af termen, særligt i studier fra USA (Jf. Donahue, 1989 eller Warner og Hefetz, 2008), har privatisering også overvejende refereret til det, vi i en dansk kontekst betegner som 'udlicitering'. Modsat både den brede og snævre anvendelse i den internationale litteratur, så er termen 'privatisering' i det almindelige danske sprogbrug overvejende anvendt som en betegnelse for frasalg af offentlige aktiviteter og virksomheder til private investorer (Jf. Jensen, 1998). I forlængelse af delvist den internationale litteraturs brede anvendelse af termen privatisering' og delvist en typologi omkring intern og ekstern 'markedsdannelse' anvendt af Højlund (2004), anvender vi termen 'ekstern markedsgørelse' i nærværende artikel. I artiklen afgrænser vi således vores terminologi fra den del af markedsgørelsen, som overvejende sker internt i den offentlige sektor, eksempelvis gennem administrative reformer, såsom resultatkontrakter og budgetreformer, eller etablering af borgerne som 'kunder' i forhold til en række offentlige services.

\section{Litteratursøgning og udvalgelse af publikationer}

Litteratursøgningen er gennemført i januar/februar 2013 og opdateret i 2015. I første omgang er litteraturen afsøgt ved hjælp af søgninger på Web of Science (Social Sciences) på udvalgte søgeord. Søgeordene har i forskellige kombinationer (og i forkortede former) omfattet 'privatization/privatisation', 'marketization/marketisation', 'contract', 'choice', 'opinion', 'public', 'citizen', 'preference' og 'attitude'. I alt er der fremsøgt 20 relevante publikationer gennem søgninger på Web of Science. I anden om- gang er referencelisterne i de først udvalgte publikationer gennemgået sammen med publikationer, der citerer de først udvalgte publikationer. Herigennem er der udvalgt yderligere en række artikler. Herudover er der medtaget publikationer, der er udgivet som notater eller rapporter, og disse er fundet ved ad hoc afsøgninger på internettet. I alt indgår 32 publikationer fra litteratursøgningen i analysen. Herudover er der inddraget relevant litteratur om andre aspekter af den eksterne markedsgørelse eller markedsgørelse mere generelt i forhold til de løbende diskussioner i artiklen.

Udvælgelsen af publikationer fra søgningerne er baseret på en gennemlæsning af publikationernes abstract og/eller indledning og konklusioner, hvorigennem der er foretaget en vurdering af publikationens relevans i forhold til afdækning og forklaring af befolkningens holdninger til ekstern markedsgørelse. I udvælgelsen har vi lagt vægt på, at befolkningens holdninger analysemæssigt har udgjort en afgørende del af den pågældende publikation.

I figur 1 er de udvalgte studier og referencer fra den samlede litteraturgennemgang oplistet efter publiceringsår og er opdelt efter afsøgningskilde. Søgningen viser, at der bortset fra et par tidlige undtagelser fra 1980'erne, løbende er publiceret omkring emnet siden sidste halvdel af 1990'erne og frem til midten af 2010'erne. Samlet set kan forskningsfeltet siges at være meget sparsomt i forhold til det samlede antal af gennemførte studier - og de gennemførte studier er spredt ud over en 30 -årig periode.

\section{Samlet oversigt}

De anvendte publikationer er gennemgået og kodet i forhold landekontekst, type af offentlig aktivitet/opgave, type af den eksterne markedsgørelse, anvendelse af be- 
folkningens holdning som afhængig eller uafhængig variabel, forskningsperspektiv- og spørgsmål, forklaringsmodeller, analysemetoder, samt datatyper og datakilder. I tabel 1 er de 32 udvalgte publikationer oplistet i forhold til forfatter, studiets udgivelsesår,, landekontekst, type af aktivitet/opgave, type af ekstern markedsgørelse, forskningsdesign, hvordan holdningen til ekstern markedsgørelse indgår som objekt eller forklarende variabel, datatype, samt anvendte erkendelsesperspektiver og forklaringsfaktorer.

I 10 ud af 32 studier indgår holdningen til den eksterne markedsgørelse, som en forklarende variabel i forhold til en anden (respons-)variabel. I de 10 studier indgår der således forskellige typer af problematiseringer af holdningen til ekstern markedsgørelse, men ikke empiriske undersøgelser af forklaringsfaktorer bag holdningen til privatisering. Tang (1997) undersøger eksempelvis, hvorvidt den eksterne markedsgørelse i USA og UK har været drevet af neokonservative og neoliberale elitære interesser fremfor bredere befolkningsmæssige præferencer. I forhold til afdækning af egentlige forklaringsfaktorer bag holdning til den eksterne markedsgørelse, afsøger 22 ud af de 32 studier sådanne på et egentligt empirisk grundlag. Langt den største del af studierne anvender kvantitative forskningsdesigns, hvor der typisk trækkes på eksisterende nationale eller internationale survey som analysegrundlag. Kun ganske få studier anvender kvalitative (2) eller 'mixed methods' (2) forskningsdesigns.

Litteraturen kan endvidere opdeles i en række komparative studier, der tager afsæt $\mathrm{i}$ internationale kvantitative datasæt på landeniveau og en række studier, som hovedsageligt tager afsæt i kvantitative datasæt for enkeltlande på enten på sektorniveau eller stats- og kommunalt niveau. En stor del af studierne af enkeltlande tager udgangspunkt i data fra meget markedsorienterede samfund, herunder USA (5 studier), UK (5 studier), Canada ( 2 studier) og Australien (1 studie). En anden del af studierne (8 studier) anvender internationale komparative data med fokus på transitionslande i særligt Østeuropa og/eller etablerede markedsøkonomier. Hertil findes en række studier med data fra enkelte europæiske lande, herunder Tyskland, Frankrig, Spanien, Sverige (3) og Norge (2), samt et par studier med landedata fra sydamerikanske lande herunder Brasilien og Argentina. Over tid er der således inkluderet studier i forskningsfeltet baseret på data fra et stadigt stigende antal lande. Størstedelen af studierne (16) tager udgangspunkt i privatisering forstået som frasalg og overdragelse af ejerskab af aktiviteter fra den offentlige til den private sektor. Indenfor det afsøgte forskningsfelt bemærker Durant og Legge (2002) at operationaliseringen af ekstern markedsgørelse, dette i form af salg til private investorer af offentligt ejede virk- somheder, kan antages at have en relativt høj profilering i den offentlige debat, hos de politiske partier, og dermed kan antages at være en velegnet markør til forståelse af holdningsdannelsen til den eksterne markedsgørelse mere generelt. En mindre del af studierne tager udgangspunkt $i$ henholdsvis udlicitering (5) eller i et mix af forskellige typer markedsgørelse mere generelt (7), såsom 'brugerbetaling', 'udlicitering' eller 'frit valg'. Kun ganske få studier tager alene udgangspunkt $i$ brugerbetaling (1) og frit valg (2). Et enkelt studie tager udgangspunkt i markedsgørelse som et generel fænomen i forhold til samfundsudviklingen. I forhold til typer af aktivitet, udgør forskellige typer af forsyningsvirksomhed eller økonomisk aktivitet (eksempelvis elforsyning eller bankvirksomhed) den største del af genstandsfeltet. Kun en mindre del omhandler det, der i en dansk sammenhæng modsvarer kerneopgaver i den universelle velfærdsstat, såsom sundhed, uddannelse eller sociale forsikringer (8). Det er også kun en mindre del (6), der undersøger holdningen til den eksterne markedsgørelse på kommunalt niveau. Lidt mere end en håndful af studierne (6) undersøger endvidere holdningen til den eksterne markedsgørelse uden reference til specifikke opgaver eller aktiviteter.

\section{Erkendelsesmæssige interesser}

Durant og Legge (2002) har i en læsning af den tidlige litteratur fremført, at forskningsområdet har været motiveret af tre forskellige erkendelsesmæssige interesser vedrørende henholdsvis 'demokratiske', 'politiske' og 'implementeringsmæssige' problemstillinger. Hertil kan der på baggrund af litteraturanalysen tilføjes en fjerde erkendelsesmæssig interesse omkring 'transformative' problemstillinger. De erkendelsesmæssige interesser og motivationer underbygger og perspektiverer de enkelte studier og undersøgelser i forskellige variationer og kombinationer. Analysen viser således, at forskningsområdet er præget af fire forskellige erkendelsesinteresser, der ikke optræder som gensidigt udelukkende:

- Et demokratisk perspektiv, der blandt andet undersøger opbakningen ud fra en problemstilling, som omhandler forskelle mellem de politiske eliters interesser og forskellige befolkningsgruppers interesser.

- Et politisk perspektiv på 'markedsgørelsens politik', der blandt andet undersøger, hvordan og hvornår politiske eliter anvender forskellige tiltag til ekstern markedsg $\varnothing$ relse, som strategi for at opnå folkelig opbakning.

- Et transformationsperspektiv, der undersøger den folkelige opbakning og holdning til ekstern markedsgørelse som en del af en bredere modernisering af de politiske institutioner i sammenhæng med større samfundsmæssige transformationer. 
Oversigt over studier i perioden 1983 til 2012 vedr. befolkningens holdning til ekstern markedsgørelse af offentlige aktiviteter

\begin{tabular}{|c|c|c|c|c|c|c|c|}
\hline $\begin{array}{l}\text { Forfatter/ } \\
\text { publiceringsår }\end{array}$ & Lande-kontekst ${ }^{\mathrm{a}}$ & Offentlig aktivitet/ opgave ${ }^{\mathrm{a}}$ & Type af markedsg. ${ }^{b}$ & \begin{tabular}{|l|}
$\begin{array}{l}\text { Markedsg. som } \\
\text { variabel }\end{array}$ \\
\end{tabular} & $\begin{array}{l}\text { Forsknings- } \\
\text { design }^{d}\end{array}$ & \begin{tabular}{|l|} 
Erkendelses- \\
interesse $^{e}$
\end{tabular} & \begin{tabular}{|l} 
Forklarings- \\
faktorer
\end{tabular} \\
\hline Judge m.fl. (1983) & UK & Forskellige velfærdsopgaver & Flere typer af markedsg. & Forklar. & Kvan. & D & - \\
\hline $\begin{array}{l}\text { Mcallister og Studlar } \\
\text { (1989) }\end{array}$ & UK & Forskellige velfærdsopgaver & Flere typer af markedsg. & Forklar. & Kvan. & D, PS, I & - \\
\hline Nelson (1997) & USA & Forskellige kommunale opgaver & Udlicitering & Forklar. & Kvan. & I & \\
\hline Tang (1997) & USA \& UK & Social forsikring & Privatisering & Forklar. & Kvan. & PS. & - \\
\hline Thompson (1997) & USA & Flere kommunale opgaver & Udlicitering & Forklar. & Kvan. & I & \\
\hline Hayo (1997) & Østeuropa, 17 lande & Statsvirksomheder & Privatisering & Objekt & Kvan. & $T$ & $E, U, I P$ \\
\hline Durant m.fl. (1998) & UK & Teleselskab & Privatisering & Forklar. & Kvan. & 1 & - \\
\hline Kinnucan m. fl. (1998) & USA & Kultur & Brugerbetaling & Objekt & Kvan. & 1 & U, IP \\
\hline Goot (1999) & Australien & Teleselskab & Privatisering & Forklar. & Kval. & PS & - \\
\hline $\begin{array}{l}\text { Thompson og Elling } \\
\text { (2000) }\end{array}$ & USA & Forskellige offentlige opgaver & Udlicitering & Objekt & Kvan. & $\mathrm{D}, \mathrm{I}$ & U \\
\hline Durant og Legge (2001) & UK & Statsvirksomheder & Privatisering & Objekt & Kval. & D & $U, I P, K$ \\
\hline Durant og Legge (2002) & Frankrig & Statsvirksomheder & Privatisering & Objekt & Kvan. & $\mathrm{D}, \mathrm{I}$ & $U, I P, K$ \\
\hline Kingstone (2003) & Brasilien & Teleselskab & Privatisering & Forklar. & Kval. & $P S, T$ & - \\
\hline Devrone (2003) & USA & Social forsikring & Privatisering & Objekt & Kvan. & D. & U, IP \\
\hline Legge og Rainey (2003) & Øst- og Vesttyskland & Elforsyning, banker, hospitaler & Privatisering & Objekt & Kvan. & D & $\mathrm{U}, \mathrm{IP}, \mathrm{K}$ \\
\hline $\begin{array}{l}\text { Lægreid og Christensen } \\
\text { (2003) }\end{array}$ & Norge & Generelt & Privatisering & Objekt & Kvan. & D & $\mathrm{IP}, \mathrm{K}$ \\
\hline Roland (2003) & Norge & Generelt & Flere typer af markedsg. & Objekt & Kvan. & D & U \\
\hline Hayo (2004) & Østeuropa, 21 lande & Generelt & Generel markedsg. & Objekt & Kvan. & $T$ & $E, U, I P, K$ \\
\hline Van de Walle (2006) & Belgien & \begin{tabular}{|l|}
$\begin{array}{l}\text { Forskellige samfundsmæssige } \\
\text { opgaver }\end{array}$ \\
\end{tabular} & Flere typer af markedsg. & Objekt & Kvan. & 1 & $\mathrm{IP}, \mathrm{K}$ \\
\hline Walks (2006) & Canada & Transport & Valg mellem off./priv. & Forklar. & Mixed & $\mathrm{D}, \mathrm{I}$ & - \\
\hline Walks (2008) & Canada & Forskellige kommunale opgaver & Privatisering & Objekt & Mixed & $\mathrm{D}, \mathrm{I}$ & $U, I P, K$ \\
\hline $\begin{array}{l}\text { Calzada og del Pino } \\
(2008)\end{array}$ & Spanien & Forskellige velfærdsopgaver & Flere typer af markedsg. & Objekt & Kvan. & $\mathrm{D}, \mathrm{I}$ & $E, U, I P$ \\
\hline $\begin{array}{l}\text { Battaglio og Leggge } \\
\text { (2008) }\end{array}$ & $\begin{array}{l}\text { International, } 17 \\
\text { lande }\end{array}$ & Hospitaler & Privatisering & Objekt & Kvan. & $\mathrm{D}, \mathrm{I}$ & $E, U, I P$ \\
\hline Battaglio (2009) & $\begin{array}{l}\text { International, } 11 \\
\text { lande } \\
\end{array}$ & Elforsyning, banker, hospitaler & Privatisering & Objekt & Kvan. & $\mathrm{D}, \mathrm{I}$ & $E, U, I P, K$ \\
\hline $\begin{array}{l}\text { Battaglio og Legge } \\
\text { (2009) }\end{array}$ & $\begin{array}{l}\text { International, } 17 \\
\text { lande }\end{array}$ & Elforsyning & Privatisering & Objekt & Kvan. & $1, T$ & $U, I P, K$ \\
\hline Denisova m.fl. (2009) & Østeuropa, 28 lande & $\begin{array}{l}\begin{array}{l}\text { Tidl. privatiserede statsvirk- } \\
\text { somneder }\end{array} \\
\end{array}$ & (af-) Privatisering & Objekt & Kvan. & $1, T$ & U, K \\
\hline Lecheler m.fl. (2009) & Denmark & Generelt & Udlicitering & Objekt & Kvan. & D, PS & E \\
\hline Jakobsen (2010) & $\begin{array}{l}\text { International, } 25 \\
\text { lande } \\
\end{array}$ & Generelt & Flere typer af markedsg. & Objekt & Kvan. & $\mathrm{D}, \mathrm{I}$ & U, K \\
\hline Di Tella m.fl. (2012) & Argentina & Vandforsyning & Privatisering & Objekt & Kvan. & I, PS & E, IP \\
\hline Edlund og Seva & Sverige & Social forsikring & Flere typer af markedsg. & Forklar. & Kvan. & D & \\
\hline Bendz (2014) & Sverige & Generelt & Udlicitering & Objekt & Kvan. & 1 & E, IP \\
\hline Bendz (2015) & Sverige & Sundhed & Frit valg & Objekt & Kvan. & D & IP \\
\hline
\end{tabular}

a. 'Landekontekst' og 'Offentlig opgave/aktivitet' beskriver henholdsvis hvilket land (eller gruppe af lande) og opgave/aktivitetsområde et studie har taget empirisk udgangspunkt i. En række studier, kategoriseret med 'generelt', har taget udgangspunkt i den overordnede holdning til ekstern markedsgørelse i det offentlige uden reference til et specifikt område.

b. Typen af ekstern markedsgørelse henviser til den form for markedsgørelse et studie, har taget empirisk udgangspunkt i. c. Markedsgørelse som variabel henviser til hvorvidt et studie har søgt at forklare holdningen til markedsgørelse (som objekt) eller hvorvidt holdningen til markedsgørelse har været anvendt til at forklare et andet fænomen ( $\mathrm{fx}$ politiske strategier).

d. Forskningsdesign henviser til hvorvidt et studie har anvendt et kvantitative (fx stort-N studie), kvalitativt (casestudie) eller 'mixed mode' forskningsdesign.

e. Erkendelsesinteresser: D=Demokratiske, PS=Politisk-strategiske, I=Implementeringsmæssige, T=Transformative.

f. Forklaringsfaktorer: E=Erfaringsmæssige, $U=U$ tilitaristiske, IP=Ideologiske-politiske, K=kulturelle. 
- Endelig undersøger et implementeringsperspektiv, hvordan befolkningens opbakning og inddragelse påvirker den eksterne markedsgørelse og dennes resultater.

Tabel 2 opsummerer den forskningsmæssige erkendelsesinteresse og en række delspørgsmål, som motiverer og begrunder studierne indenfor forskningsområdet. I forhold til den forskningsmæssige motivation inddrager i alt 18 studier et demokratisk perspektiv, 18 studier et implementeringsmæssigt perspektiv, 5 studier et transformativt perspektiv og 6 studier et politisk-strategisk perspektiv (jf. Tabel 1).

\section{Demokratiske erkendelsesinteresser}

Blandt andet Tang (1997) og Durant og Legge (2002) diskuterer, hvorvidt ekstern markedsgørelse kan antages at været mere drevet af politiske eliter og deres mere snævre interesser end funderet i bredere befolkningsmæssige interesser. Implementeringen af den eksterne markedsgørelse antages herfor at have karakter af elitære eller ideologiske projekter påført oppefra, uden der sker inddragelse af eller forankring i befolkningen undervejs. Flere studier påpeger her, at privatisering er forbundet med komplicerede teknokratiske processer og problemstillinger, hvor folkelig inddragelse i beslutningsprocesserne kan være vanskelig (Thompson \& Elling, 2000). Markedsgørelse kan derfor have karakter af en politik, der igennem beslutningsprocesser i mere lukkede fora fremmer nogle gruppers interesser på bekostning af andre gruppers, og samtidig sker på grundlag af og i processer, som er demokratisk ekskluderende. Med udgangspunkt i en problematisering med henvisning til demokratisk styring og demokratiske beslutningsprocesser, er forskningsspørgsmålene om den eksterne markedsgørelse og befolkningens holdning hertil således fokuseret på forde- lingspolitik, varetagelse af særinteresser, samt demokratiske underskud i beslutningsprocesserne. Thompson og Elling (2000) påpeger, at det er et demokratisk styringsproblem med implikationer for de politiske institutioner og processer (eksempelvis legitimering af beslutninger vedrørende privatisering), hvis de væsentlige samfundsmæssige reformtrends (såsom privatisering og deregulering) ikke forstås af offentligheden. Og ligeledes hvis de politiske beslutninger ikke er i overensstemmelse med offentlighedens holdninger og opfattelser.

I forhold til problemet med et eventuelt demokratisk underskud og den elitære karakter af markedsgørelse, viser studier af Judge m.fl. (1983) og Tang (1997) dog også, at der kan være en bred opbakning i befolkningen til øget markedsgørelse, som går hånd i hånd med en mere overordnet opbakning til velfærdsstaten. Studiet af Judge m.fl. (1983) fremhæver, at privatisering i det engelske sundhedsvæsen havde en bred forankring i den engelske befolkning i den analyserede periode. Studiet påpeger endvidere, at den eksterne markedsgørelse ikke nødvendigvis er et spørgsmål for befolkningen om en større eller mindre rolle for staten i produktionen af velfærd. Holdningen kan også være et udtryk for en pluralistisk holdning og accept af en blandingsøkonomi, hvor staten har et forvaltningsmæssigt ansvar og regulativ rolle, og hvor markedet anvendes som middel til levering af velfærdsgoder. Et senere studie af Edlund og Seva (2013) har i samme perspektiv også undersøgt befolkningens holdning til markedsgørelse, som del af mere overordnende skift i opbakningen til forskellige typer af velfærdsstatsmodeller.

\section{Politisk-strategiske erkendelsesinteresser}

I flere studier fremhæves det, at politiske ledere og den offentlige administration forsøger at tage højde for befolk-

Tabel 2. Fire forskningsmæssige erkendelsesinteresser og delspørgsmål.

\begin{tabular}{|c|c|c|}
\hline Erkendelsesinteresse & Delspørgsmål & Eksempler på studier \\
\hline \multirow{3}{*}{$\begin{array}{l}\text { Demokratiske } \\
\text { erkendelsesinteresser }\end{array}$} & Privatisering som elitært/teknokratisk projekt med et demokratisk underskud? & Durant og Legge (2002), Thompson og Elling (2000) \\
\hline & Opbakning til forskellige typer velfærdsstater / økonomier? & Judge m.fl. (1983), Edlund og Seva (2013) \\
\hline & Manglende viden om og interesse i privatisering? & Thompson (1997) \\
\hline \multirow{2}{*}{$\begin{array}{l}\text { Politisk-strategiske } \\
\text { erkendelsesinteresser }\end{array}$} & Privatisering som del af politiske strategier ('privatiseringens politik')? & Goot (1999), Kingstone (2003) \\
\hline & Påvirkning af privatisering på stemmeafgivning ved valg? & McAllister og Studlar (1989) \\
\hline \multirow[t]{2}{*}{$\begin{array}{l}\text { Transformative } \\
\text { erkendelsesinteresser }\end{array}$} & $\begin{array}{l}\text { Privatisering som del af opbakning til udvikling af markedsøkonomi i } \\
\text { transitionsøkonomier? }\end{array}$ & Hayo (2004) \\
\hline & $\begin{array}{l}\text { Privatisering som del af politisk modernisering / konsolidering af } \\
\text { demokratiske institutioner? }\end{array}$ & Kingstone (2003) \\
\hline \multirow[t]{3}{*}{$\begin{array}{l}\text { Implementeringsmæssige } \\
\text { erkendelsesinteresser }\end{array}$} & Opbakning som forudsætning for implementering af privatisering? & $\begin{array}{l}\text { McAllister og Studlar (1989), Thompson og Elling } \\
\text { (2000) }\end{array}$ \\
\hline & Kontrol af privatisering via inddragelse i implementeringen? & Durant m.fl. (1998) \\
\hline & Befolkningens positive evaluering som forudsætning for fortsat privatisering? & Thompson (1997) \\
\hline
\end{tabular}


ningens holdninger. Studier af eksempelvis McAllister og Studlar (1989), Goot (1999) og Kingstone (2003) understreger vigtigheden af inddragelsen af befolkningens holdning og støtte til ekstern markedsgørelse i forhold til politiske strategier og programmer. Goot (1999) undersøger eksempelvis „markedsgørelsens politik“ gennem et studie af den australske befolknings holdning til privatisering af det statslige telefonselskab, og hvordan denne holdning indgik i forskellige valgstrategier for regering og opposition ved valget til det australske parlament $\mathrm{i}$ 1996. Denne sammenhæng indgår også i Kingstone (2003) studie af privatiseringen af det tidligere statsejede telefonselskab i Brasilien, hvor overvejelser om graden af befolkningens støtte og opbakning til gennemførelsen af privatiseringen ligeledes indgik i regeringens og oppositionens forskellige politiske strategier og programmer. McAllister og Studlar (1989) finder ligeledes, at politiske partiers politikker vedrørende øget privatisering har bidraget til at vinde (eller tabe) stemmer ved de nationale valg i England i 1980'erne.

\section{Transformative erkendelsesinteresser}

De fleste studier omkring markedsgørelse kan ses i et reform- eller transitionsperspektiv, hvor markedsgørelse er en del af en større eller mindre omlægning af ansvar og fordeling af samfundsmæssige opgave mellem det offentlige og private. En række studier indeholder dog et dybere og eksplicit transformativt perspektiv, hvor eksempelvis centrale politiske institutioner ses undergå en udvikling/ modernisering i sammenhæng med mere overordnede samfundsmæssige forandringer.

Det er særligt studier af transitionslandene i $\varnothing_{\text {st- }}$ europa, eksempelvis af Denisova m.fl. (2009) og Hayo (2004) og af ny-industrialiserede lande, eksempelvis af Kingstone (2003), som indeholder et dybere transformativt aspekt. I studiet af Kingstone (2003) bliver den succesfulde privatisering af et ineffektivt statsligt selskab eksempelvis udpeget som en afgørende begivenhed i udviklingen af effektive politiske institutioner i det brasilianske demokrati. Hayo (1997) og Hayo (2004) undersøger ligeledes graden af særligt privatiseringer som en del af forklaringen på befolkningernes opbakning til udvikling af markedsøkonomier i Østeuropa.

Transformative problemstillinger indgår dog også i enkelte studier gennemført i etablerede markedsøkonomier. Christensen og Lægreid (2003) anvender eksempelvis en transformation af den norske befolknings generelle holdningssæt ('modernistholdninger') som forklaring på en positiv holdning til privatisering af offentlige selskaber. Christensen og Lægreid (2003) udpeger således en overordnet holdningsmæssig transformation som forklaring på skift i holdningen til ekstern markedsgørelse.

\section{Implementeringsmæssige erkendelsesinteresser}

Implementeringsmæssige problemstillinger omhandler blandt andet samspillet mellem ekstern markedsgørelse og befolkningens holdning og opbakning i forhold til implementeringen af markedsgørelse, eksempelvis gennem påvirkningen af holdninger og opbakning gennem viden og erfaringer med implementering af markedsgørelse indenfor specifikke opgaver. Savas (2000) har overordet påpeget befolkningens opbakning som drivkraft og afg $\varnothing$ rende forudsætning for implementeringer af markedsg $\varnothing$ relse. McAllister og Studlar (1989) påpeger ligeledes, i en perspektivering af 1980'ernes privatiseringsbølge i England, at uden befolkningens indledningsvise opbakning, så risikerer mere vanskelige og langstrakte privatiseringer, hvor det eksempelvis er svært at tiltrække privat kapital, at ende i mislykkede privatiseringer, fordi befolkningens opbakning daler undervejs.

I et studie af privatiseringen af det tidligere statsejede engelske teleselskab, British Telecom, påpeger Durant m.fl. (1998) et andet vigtigt aspekt ved befolkningens holdninger i privatiseringsprocesser. De konkluderer på baggrund af deres analyse, at befolkningens aktive deltagelse og bevågenhed var kritisk for succesfuld implementering og opnåelse af overordnede samfundsmæssige og økonomiske målsætninger. Offentlig afrapportering af indikatorer for servicekvalitet var i privatiseringen af British Telecom en vigtig kontrolfunktion og performancefremmende foranstaltning.

I et implementeringsperspektiv kan det endvidere forventes, at befolkningens positive eller negative evaluering af områder, hvor der allerede er gennemført en markedsgørelse, vil påvirke opbakningen til ekstern markedsgørelse indenfor andre områder. Thompson (1997) påpeger eksempelvis på denne baggrund, at borgernes holdninger og præferencer kan sinke eller vanskeliggøre implementering af nye alternative måder at levere og producere offentlige serviceydelser. Thompson og Elling (2000) fremhæver ligeledes som en indledningsvis begrundelse, at de implementeringsmæssige problemer, der kan opstå såfremt at den eksterne markedsgørelsen, sker i modsætning til offentlighedens holdninger - eller omvendt - hvordan befolkningens holdning kan understøtte markedsgørelse.

\section{Forklaringsmodeller}

Ovenfor har vi gennemgået fire centrale begrundelser, der motiverer studierne af befolkningens holdninger til markedsgørelse. Nedenfor fortsætter vi med at gennemgå og diskutere, hvordan studierne indenfor forskningsfeltet har forsøgt at forklare forskelle i befolkningens holdning. Med udgangspunkt i en række foreløbige forklaringsmodeller, der fremsættes af Durant og Legge (2001), som 
forsøg på at samle en række mulige forklaringer indenfor forskningsområdet undersøger Durant og Legge (2002), hvordan holdninger til privatisering af statsejede virksomheder i Frankrig varierer mellem forskellige befolkningsgrupper, samt afdækker forklaringskraften i seks forskellige forklaringsfaktorer. Faktorerne omfatter hypoteser omkring henholdsvis utilitaristiske vurderinger, økonomiske vurderinger, opbakning til politisk ledelse, ideologisk orientering, værdiorientering samt efterligning af erfaringer fra andre lande ('emulering'). I senere og tidligere studier indgår sådanne forklaringsmodeller på forskelligvis. Hvor Battaglio og Legge (2008) eksempelvis anvender en opdeling mellem det 'symbolske' og det 'egennyttige', som to hovedgrupper af forklaringer, anvender Battaglio (2009) nationale og branche specifikke forskelle, utilitaristiske overvejelser, politik lederskab, partipolitik orientering samt værdiorientering som fem hovedgrupper af forklaringer.

Flere studier anvender endvidere en kombination af forklaringsmodeller i opbygningen af specifikke hypoteser. Dette gælder eksempelvis i studiet af Battaglio (2009), hvor postmaterialistiske værdier forventes at påvirke holdningen til privatisering i negativ retning, blandt andet fordi privatisering formodes at mindske den politiske indflydelse i de tilfælde, hvor der foreligger et velfungerende medborgerskab. I denne forklaringsmodel kombineres således en utilitaristisk (vurdering af indflydelse) med en værdiorienteret forklaring.

Samlet set synes forskningsområdet at kunne inddeles meningsfuldt i fire hovedgrupper af forklaringsmodeller, herunder:

- Erfaringsbaserede forklaringer, hvor forklaringer blandt andet tager udgangspunkt i direkte og indirekte erfaringer samt viden (eller manglende viden) om konkrete tiltag og processer.
- Utilitaristiske forklaringer, hvor forklaringerne på befolkningens holdning og opbakning forklares ud fra borgernes vurdering af den eksterne markedsgørelses påvirkning i forhold til deres økonomiske situation, deres jobsituation og jobmuligheder samt deres politiske indflydelse.

- Ideologisk-politiske forklaringer, hvor forklaringer tager udgangspunkt i politisk tilhørsforhold og ideologiske overbevisning men også tillid til et politiskadministrativt lederskab.

- Værdiorienterede og kulturelle forklaringer, hvor forklaringer tager udgangspunkt i dybere værdisæt og/ eller kulturelle træk hos befolkningen.

I Tabel 3 opsummeres de forskellige forklaringer i fire hovedgrupper af forklaringsmodeller samt en række variationer, der anvendes i forskellige studier. I alt belyser 16 studier betydningen af utilitaristiske faktorer, 18 studier betydningen af ideologiske/politiske faktorer, 11 studier betydningen af værdimæssige/kulturelle faktorer samt 9 studier betydningen af erfaring og viden som faktorer (jf. Tabel 1).

\section{Erfarings- og vidensbaserede forklaringer}

En del af de gennemgåede studier undersøger betydningen af befolkningens erfaringer og viden om privatisering i forhold til holdningsdannelsen. Thompson (1997) påpeger, $\mathrm{i}$ et studie af borgernes holdning og viden om udlicitering i en række byområder i det sydlige Michigan, USA, at borgerne på lokalt plan og i forhold til konkrete forhold kan være forholdsvis uvidende om, hvordan lokale myndigheder organiserer produktionen af forskellige offentlige services. Væsentlige konklusioner i dette studie er, at der kun er meget begrænset sammenhæng mellem tilfredshed og produktionsmåde, at borgernes viden om, hvordan produktion og levering er organiseret, generelt

Tabel 3. Fire forklaringsmodeller og variationer

\begin{tabular}{lll} 
Forklaringsmodeller & Variationer & Eksempler på studier \\
\hline Erfaringsbaserede & Viden om/erfaring med konkrete forløb & Di Tella m.fl. (2012) \\
& Sværhedsgraden af privatiseringen & McAllister og Studlar (1989) \\
& Holdningsdannelse gennem erfaring af bymiljøer & Walks (2008) \\
\hline Utilitaristiske & Vurdering i forhold til egen økonomisk situation & Thompson og Elling (2000) \\
& Vurdering i forhold til egne jobmuligheder & Denisova m.fl. (2009) \\
& Vurdering i forhold til egen politisk indflydelse & Battaglio (2009) \\
\hline Ideologiske-politiske & Politisk/ideologisk tilhørsforhold & Tang (1997) \\
& Tillid til politisk-administrativt lederskab & Battaglio (2009) \\
\hline Værdiorienterede og kulturelle & Postmodernistisk værdiorientering & Durant og Legge (2001) \\
& Personlig værdiorientering & Jakobsen (2010) \\
& Emulgeringshypotese & Durant og Legge (2002) \\
& Nationale karakteristika (kultur) & Battaglio og Legge (2008) \\
\hline
\end{tabular}


set er lav, samt at langt størstedelen af borgerne er 'konservative' i deres holdning, forstået således, at de foretrækker at produktion og levering bevares, som de tror, den allerede er organiseret. I et komparativt studie af holdninger til privatisering af hospitaler i 17 lande antager Battaglio og Legge (2008), at jo bedre informeret og vidende borgerne er om politik, jo mere tydelige vil de være i deres stillingtagen til privatisering. Battaglio og Legge (2008) finder en sammenhæng mellem et højere selvoplevet informationsniveau og en positiv holdning til privatisering. Battaglio (2009) bekræfter de fundne sammenhænge i et senere komparativt studie af holdningen til privatisering af banker, elforsyning og hospitaler i 11 lande.

I et studie af Di Tella m.fl. (2012) undersøges viden om og erfaringer med privatisering i Argentina i form af, hvorvidt graden af nyinvesteringer, foretaget af private virksomheder i forbindelse med privatisering af vandforsyning, påvirker befolkningens holdning positivt, samt om negativ omtale i medierne ('politisk propaganda') påvirker holdningen negativt. I studiet konkluderes det blandt andet, at både viden om ny-investeringer (erfaringer) samt eventuel negativ omtale påvirker befolkningens holdning som forventet. Di Tella m.fl. (2012) påpeger således et indre dynamisk aspekt ved sammenhængen mellem privatisering og holdningen hertil, hvor selve privatiseringens forløb, omtale og resultat er med til at forme holdningen.

En anden erfaringsbaseret forklaring, der udforskes i to studier af Walks, er, at sociale og fysiske omgivelser (typen af bymiljø) former de politiske præferencer (2006; 2008). Walks' studier peger på, at oplevelsen af forskellighed i bykerner, eksempelvis af fattigdom, medfører en større forståelse for mangfoldigheden i essentielle behov, som hører ind under et offentligt ansvar, hvorimod oplevelsen i de mere monotone forstadsmiljøer medfører en mindre forståelse af mangfoldighed og nødvendigheden af et (større) offentligt ansvar. Forstædernes bymiljø fremmer således en positiv holdning til anvendelse af private løsninger, hvorimod bykernes bymiljø medfører en mere positiv holdning til offentlige løsninger.

En lidt anderledes måde at anvende erfaring og viden som forklaring forefindes hos Calzada og del Pino (2008). I et studie af den spanske befolknings holdning til reformer af traditionelle velfærdsprogrammer finder Calzada og del Pino (2008) at opfattelsen af nogle velfærdsprogrammer som ineffektive, kan forklare en befolkningsmæssig opbakning til en større grad af involvering af private leverandører i offentlige serviceproduktion. Denne forklaringsmodel tager således udgangspunkt i en mere pragmatisk orienteret forståelse af de forhold, der former holdningen til markedsgørelse. De centrale spørgsmål i denne forklaring hos Calzada og del Pino (2008) er, om befolkningen har en opfattelse af, at der behov for reformer, og om markedsgørelse er et effektivt middel hertil.

\section{Utilitaristiske forklaringer}

Den utilitaristiske forklaringsmodel forklarer holdninger som en funktion af, hvordan borgerne, på baggrund af eksempelvis demografiske eller socioøkonomiske karakteristika, vurderer den direkte påvirkning af en given policy på deres økonomiske situation (Durant og Legge, 2001; 2002). Markedsgørelsens betydning i forhold til økonomiske egeninteresser står helt centralt i forklaringsmodellen (jf. Battaglio og Legge, 2009). Generelt underbygger studierne den utilitaristiske forklaringsmodel, som helt central i forklaringer af holdningen til markedsgørelse. Eksempelvis underbygger Devroye (2003) og Battaglio (2009), med udgangspunkt i en utilitaristisk forklaringsmodel, at befolkningsgrupper med lavere indkomster samt lavere uddannelsesniveau vil være mere negativt indstillet overfor privatiseringer, da privatiseringer antages, at ville blive evalueret som truende i forhold til individets økonomiske situation. I den utilitaristiske model forventes befolkningsgrupper med højere indkomster og højere uddannelsesniveau omvendt at være neutralt eller positivt indstillet overfor markedsgørelse. I forhold til ældre, kvinder og andre grupper, der har en større afhængighed af offentlige serviceydelser forventes det ligeledes, at holdningen vil være mere negativ. Ligeledes med udgangspunkt i en utilitaristisk forklaringsmodel, undersøger og bekræfter Denisova m.fl. (2009) sammenhængen mellem enkeltpersoners jobkompetencer i forhold til en markedsøkonomisk baseret økonomi og opbakningen til privatiseringer og samfundsmæssige reformer i en række østeuropæiske transitionslande.

\section{Ideologisk-politiske forklaringer}

I en stor del af analyserne forventes holdingen til konkrete tiltag og programmer, der fremmer markedsgørelse, at kunne forklares ved hjælp af individers partipolitiske tilhørsforhold og overordnede ideologiske orientering (Battaglio og Legge, 2009; Durant og Legge, 2002; Tang, 1997; Thompson og Elling, 2000). Givet den historisk set centrale placering af privatisering af statsejede virksomheder på den politiske agenda, som omdrejningspunkt for meningsforskelle og retoriske positioner mellem venstre- og højreorienterede partier (og de bagvedliggende ideologier), er det forventet, at befolkningens holdning, særligt for denne form for markedsgørelse, kan forklares med udgangspunkt i den partipolitiske og ideologiske orientering (Durant og Legge, 2002).

Den generelle opbakning og tillid til et politisk lederskab og til dels ledere i den offentlige administration, er også anvendt som en forklaring på befolkningens 
holdning til særligt privatisering $\mathrm{i}$ enkelte studier. Battaglio (2009) påpeger her, at politikere - og til dels embedsmænd - i flere tilfælde har anvendt gennemførelse af privatiseringer som et led i deres karriere. En positiv holdning i befolkningen til markedsgørelse forklares her som en funktion af opbakning og tillid til det politiske lederskab. I det konkrete studie finder Battaglio (2009) dog ikke empirisk belæg for sammenhængen.

\section{Værdiorienterede og kulturelle forklaringer}

En værdiorienteret forklaringsmodel, hos blandt andre Durant og Legge (2001) og Battaglio (2009), tager udgangspunkt i Ingleharts (1990) overvejelser omkring borgernes værdimæssige orientering i postmaterialistiske samfund. Den øgede tilfredsstillelse af befolkningernes basale økonomiske og sikkerhedsmæssige behov i efterkrigstidens samfund i den vestlige verden medfører, ifølge denne forklaring, en orientering mod postmaterialistiske værdier såsom deltagelse, lighed, selvrealisering og lokale fællesskaber. I et postmaterialistisk perspektiv kan markedsgørelse ses som en reduktion af mulighederne for politisk indflydelse. Borgere, der føler at det politiske medborgerskab er velfungerende, og oplever, at de har en højere grad af politisk indflydelse, vil derfor vurdere at markedsgørelse mindsker deres indflydelse og derfor være imod markedsgørelse (Battaglio, 2009, s. 48-9). Orienteringen i forhold til henholdsvis materielle versus postmaterielle værdier forventes således at kunne forklare holdningen til markedsgørelse.

Betydningen af den nationale og/eller kulturelle kontekst er også undersøgt i en række studier. Den generelle præference og holdning til markedsgørelse og markedets rolle forventes her, at være højere i nogle lande på grund af historiske og kulturelle forhold. Battaglio (2009) fremhæver eksempelvis USA, som et eksempel på en national kontekst, hvor den historiske opbakning til markedets rolle i samfundet har været størst og mest positiv i sammenligning med andre udviklede markedsøkonomier. Ligeledes med udgangspunkt i et komparativt perspektiv, opstiller Durant og Legge (2002) en 'emulgeringshypotese'. I dette perspektiv forventer Durant og Legge (2002), at befolkningen i et land vil være mere positive overfor markedsgørelse, såfremt at markedsgørelse har været succesfulde implementeret i lande, som udgør et forbillede for den pågældende befolkning.

\section{Diskussion}

Samlet set er den internationale forskning i befolkningens holdninger til den eksterne markedsgørelse forholdsvis begrænset i omfang. Forskningsområdet har siden 1980'erne, trods den begrænsede mængde af studier, udvist en progression i udviklingen af forklaringsmodeller og gennemførelsen af studier indenfor stadigt flere forskellige sammenhænge (eksempelvis lande og serviceområder). Særligt siden starten af 2000'erne er en række studier begyndt at udgøre et samlet forskningsfelt gennem konsolidering af en række problemfelter og forklaringsmodeller. Det kan endvidere påpeges, at de forskellige studier indenfor forskningsfeltet i det store hele bekræfter relevansen af de forskellige forklaringsmodeller.

Samlet set kan forskningsområdet, på baggrund af litteraturgennemgangen, siges at centrere sig omkring fire erkendelsesinteresser og fire grupper af forklaringsmodeller. I Tabel 1 er de anvendte erkendelsesinteresser og forklaringsmodeller for hvert enkelt studie gengivet. Ud fra Tabel $1 \mathrm{kan}$ det ses, at den del af studierne, der anvender befolkningens holdning som objekt ( $20 \mathrm{i}$ alt), i forskellig grad trækker på de i alt 16 forskellige mulige kombinationer af erkendelsesinteresser og forklaringsmodeller. I Tabel 4 angives fordelingen af de forskellige kombinationer på tværs af alle studier. I de 22 studier, der anvender befolkningens holdning som objekt, afdækker studiet af Battaglio (2009) flest kombinationer (8), mens en række studier, eksempelvis Roland (2003) eller Judge m.fl. (1983), kun afdækker en enkelt kombination. Ud fra fordelingen ses det, at denne del af forskningsfeltet særligt har været koncentreret omkring demokratiske og implementeringsmæssige erkendelsesinteresser i kombination med særligt utilitaristiske og ideologiske-politiske forklaringsmodeller. I forhold til anvendelse af forklaringsmodeller har erfaringer/viden samt de kulturelle/værdimæssige været lidt mindre anvendt. De politisk-strategiske og til dels de transformative erkendelsesinteresser har samlet set været mindre udbredt. Dog er de politisk-strategiske erkendelsesinteresser relativt mere udbredt i gruppen af de i alt 10 studier, der anvender befolkningens holdning som forklarende variabel.

Fremadrettet bør opgørelsen i Tabel 4 kunne fungere som et udgangspunkt for målretning og udvikling af forskningsfeltet. Eksempelvis er der få studier, der anvender en politisk-strategisk erkendelsesinteresse, og dette perspektiv på befolkningens holdning til den eksterne markedsgørelse synes således underbelyst indenfor forskningsfeltet i forhold til studier, der eksempelvis har en implementeringsmæssig interesse.

Vores gennemgang viser endvidere, at der har været en skævhed i forhold til de former for ekstern markedsgørelse, som befolkningens holdning er undersøgt op imod. I den undersøgte periode har forskningsfeltet særligt været præget af studier, der fokuserer på privatisering af statslige selskaber. Derimod er der kun en mindre del af studierne, som undersøger holdningen til eksempelvis udlicitering og frit valg. Det kan også påpeges, at det kun er ganske få af studierne, som undersøger forskelle i 
Tabel 4. Fordeling af kombinationer af erkendelsesinteresser og forklaringsmodeller på tværs af studier af befolkningens holding til ekstern markedsgørelse

\begin{tabular}{|c|c|c|c|c|}
\hline \multirow[b]{2}{*}{ Forklaringsmodeller } & \multicolumn{4}{|c|}{ Erkendelsesinteresser } \\
\hline & Demokratiske & Politisk-strategiske & Transformative & Implementerings-mæssige \\
\hline Erfaring / viden & 4 & 2 & 3 & 6 \\
\hline Utilitaristiske & 11 & 0 & 4 & 10 \\
\hline Ideologiske / politiske & 10 & 1 & 3 & 10 \\
\hline Værdier / Kultur & 7 & 0 & 3 & 7 \\
\hline Ingen* & 4 & 4 & 1 & 5 \\
\hline Total & 36 & 7 & 14 & 38 \\
\hline
\end{tabular}

Tabellen angiver antallet af kombinationer af erkendelsesinteresser og forklaringsmodeller på tværs af de 32 indgående studier i litteraturgennemgangen. I de 2 studier, der anvender befolkningens holdning som objekt afdækker studiet af Battaglio (2009) flest kombinationer (8) mens studiet af Roland (2003) afdækker færrest (1).

* Denne kategori inkluderer kun fordelingen af erkendelsesinteresser i de 10 studier, der anvender befolkningens holdning som forklaring på et andet fænomen.

holdningen til ekstern markedsgørelse mellem forskellige typer af opgaver, samt tager udgangspunkt i opgaver, som løses på kommunalt plan. Forskningsfeltet kan således siges, at have en grad af skævhed i forhold til de former for ekstern markedsgørelse, som er gjort til genstand for undersøgelse af befolkningens holdning. Forskningsfeltet har endvidere ikke omhandlet nyere former for ekstern markedsgørelse, såsom offentlige-private partnerskaber, der internationalt set har været under udbredelse siden starten af 2000'erne (Hodge m.fl., 2012). En række af studierne undersøger dog den generelle holdning til den eksterne markedsgørelse. Denne gruppe af studier kan således siges at dække flere former for markedsgørelse indenfor den historiske landekontekst, de er gennemført i. I sådanne studier er det dog et åbent spørgsmål hvilken form for ekstern markedsgørelse, og hvilke konkrete sammenhænge respondenterne har haft i tankerne, når de har svaret på deres holdning hertil.

Den nærværende gennemgang har i alt væsentlighed gennemgået forskningsfeltets egne forklaringsmodeller på befolkningens holdning til ekstern markedsgørelse. Studierne er eksempelvis ikke gennemgået for eventuel sammenhæng med den mere generelle politologi omkring politisk holdningsdannelse. Det nærværende forskningsfelt kunne derfor yderligere vurderes og potentielt udvikles ved at koble til den mere generelle politologi om holdningsdannelse.

I et policy-perspektiv på ekstern markedsgørelse er det centrale spørgsmål, hvorvidt de forskellige former præsterer i forhold til deres primære målsætninger ( $\mathrm{fx}$ kvalitet og økonomi) samt bredere organisatoriske og samfundsmæssige effekter (Lundqvist, 1989). En bedre forståelse af befolkningens holdning til ekstern markedsgørelse bør kunne bidrage til at forklare eksempelvis forskellige politiske strategier og dermed bidrage til en mere velfunderet forståelse af markedsgørelsens udbredelse i den danske offentlige sektor.

\section{Konklusion}

Dansk politologisk forskning i den eksterne markedsgørelse af den offentlige sektors organisationer og aktiviteter har tidligere ikke haft fokus på den bredere befolknings holdninger. Modsat er der i den internationale litteratur i de seneste 30 år udviklet et mindre forskningsfelt på området, som denne artikel har undersøgt i forhold til tværgående erkendelsesinteresser og anvendte forklaringsmodeller. Vores analyser har afdækket fire gennemgående erkendelsesinteresser og fire forklaringsmodeller, der kombineres på forskelligvis i den internationale politologiske forskning. Erkendelsesinteresserne omhandler demokratiske, politisk-strategiske, transformative og implementeringsmæssige perspektiver og forklaringsmodellerne omhandler erfaringsmæssige, utilitaristiske, ideologiske-politiske og kulturelle perspektiver. Overordnet set har forskningsfeltet særligt været præget af demokratiske og implementeringsmæssige erkendelsesinteresser samt utilitaristiske og ideologiske-politiske forklaringsmodeller. Derimod har eksempelvis erfaringsbaserede forklaringsmodeller været forbavsende underprioriteret. De typologier, vi har udviklet, indikerer således, at forskningsfeltet er præget af en række skævheder i forhold til anvendte erkendelsesinteresser og forklaringsmodeller. 
Endvidere er der en mangel på studier, der kan belyse flere af den eksterne markedsgørelses forskellige former samt studier, der belyser ekstern markedsgørelse på tværs af forskellige typer af serviceområder på eksempelvis kommunalt niveau. Samlet set kan vores gennemgang af den internationale litteratur bidrage til at inspirere den fremtidige forskning i forhold til yderligere afdækning af eksempelvis politiske strategier og implementering af forskellige former for ekstern markedsgørelse samt - ikke mindst - i forhold til afdækning af en dansk kontekst.

\section{Litteraturliste}

Andersen, N.Å. (1997). Udlicitering - Strategi og Historie. Frederiksberg: Nyt fra Samfundsvidenskaberne.

Battaglio, R.P., Jr. \& Legge, J.S., Jr. (2008). Citizen Support for Hospital Privatization: A Hierarchical Cross-National Analysis. Public Organization Review, 8(1), 17-36.

Battaglio, R.P., Jr. (2009). Privatization and Citizen Preferences: A Cross-National Analysis of Demand for Private versus Public Provision of Services in Three Industries. Administration \& Society, 41(1), 38-66.

Battaglio, R.P., Jr. \& Legge, J.S., Jr. (2009). Self-Interest, Symbolic Politics, and Citizen Characteristics: A Cross-National Analysis of Support for Privatization. Public Administration Review, 69(4), 697-709.

Bendz, A. (2014). Att ge feedback på välfärdspolitiken: hur reagerar medborgarna på ökad privatisering? In H. Oscarsson, \& A. Bergström (Eds.). Mittfära och marginal. (pp. 295-305). Göteborg: SOM-Instituttet.

Bendz, A. (2015). Paying Attention to Politics: Public Responsiveness and Welfare Policy Change. Policy Studies Journal, 43(3), 309-332.

Christensen, L.R., Houlberg, K. \& Petersen, O.H. (2012). Udlicitering eller egenproduktion - Hvordan forklarer den politologiske litteratur de store forskelle i kommunernes brug af private leverandører i opgaveløsningen? Politik, 15(2), 44-55.

Christensen, T., \& Lægreid, P. (2003). Politisk styring og privatisering: holdninger i elitene og befolkningen. Norge: Stein Rokkan senter for flerfaglige samfunnsstudier.

Christensen, L.R. \& Petersen, O.H. (2010). Regulering af udlicitering og offentlige-private partnerskaber (OPP) i de danske kommuner. Politica, 42(2), 235-257.

Denisova, I., Eller, M., Frye, T. \& Zhuravskaya, E. (2009). Who Wants To Revise Privatization? The Complementarity of Market Skills and Institutions. The American Political Science Review, 103(2), 284-304.

Devroye, D. (2003). Who Wants to Privatize Social Security? Understanding Why the Poor Are Wary of Private Accounts. Public Administration Review, 63(3), 316-328.

Di Tella, R., Galiani, S. \& Schargrodsky, E. (2012). Reality versus propaganda in the formation of beliefs about privatization. Journal of Public Economics, 96(5-6), 553-567.

Donahue, J.D. (1989). The privatization decision: Public ends, private means. New York: Basic Books.

Durant, R.F., Legge, J.S., Jr. \& Moussios, A. (1998). People, profits, and service delivery: Lessons from the privatization of British Telecom. American Journal of Political Science, 42(1), 117-140.

Durant, R.F. \& Legge, J.S., Jr. (2001). Politics, public opinion, and privatization: A test of competing theories in Great Britain. Public Organization Review, 1(1), 75-95.
--- (2002). Politics, public opinion, and privatization in France: Assessing the calculus of consent for market reforms. Public Administration Review, 62(3), 307-323.

Edlund, J. \& Seva, I.J. (2013). Is Sweden Being Torn Apart? Privatization and Old and New Patterns of Welfare State Support. Social Policy \& Administration, 47(5), 542-564.

Ejersbo, N. \& Greve, C. (2014). Moderniseringen af den offentlige sektor. København: Akademisk Forlag.

Goot, M. (1999). Public Opinion, Privatisation and the Electoral Politics of Telstra. Australian Journal of Politics \& History, 45(2), 214238.

Greve, C. (2000). Statens Virksomheder: Aktieselskabsdannelse og privatisering i 1990'erne. København: Jurist- og Økonomiforbundets Forlag.

Greve, C. \& Ejersbo, N. (2005). Contracts as Reinvented Institutions in the Public Sector: A Cross-Cultural Comparison. Westport: Praeger.

Grønnegård, J. \& Pallesen, T. (2001). The Political Benefits of Corporatization and Privatization. Journal of Public Policy, 21(3), 283-309.

Hansen, M.B. (2011). Antecedents of Organizational Innovation: The Diffusion of New Public Management Into Danish Local Government. Public Administration, 89(2), 285-306.

Hansen, M.B. (2013). Transnational organisatorisk innovation i den offentlige sektor. Politica, 45(3), 267-286.

Hayo, B. (1997). Eastern European Public Opinion on Economic Issues: Privatization and Transformation. American Journal of Economics and Sociology, 56(1), 85-102.

--- (2004). Public support for creating a market economy in Eastern Europe. Journal of Comparative Economics, 32(4), 720-744.

Hjelmar, O., Petersen, O.H. \& Vrangbæk, K. (2013). Udlicitering af offentlige opgaver i Danmark: En forskningsoversigt over hidtil dokumenterede effekter. Politica, 45(1), 60-79.

Hodge, G.A. (2000). Privatization - An International Review of Performance. Oxford: Boulder Westview Press.

Hodge, G.A., Greve, C. \& Boardman, A.E. (red). (2012). International Handbook on Public-Private Partnerships. Cheltenham: Edward Edgar.

Hood, C. (1991). A Public Management for All Seasons?. Public Administration, 69(1), 3-19.

Højlund, H. (2004). Markedets politiske fornuft. Et studie af velfardens organisering 1990-2003. København: Nyt fra Samfundsvidenskaberne.

Inglehart, R. (1990). Culture Shift. Princeton: Princeton University Press.

Jakobsen, T.G. (2010). Public versus Private: The Conditional Effect of State Policy and Institutional Trust on Mass Opinion. European Sociological Review, 26(3), 307-318.

Jensen, L. (1998). Interpreting New Public Management: The Case of Denmark. Australian Journal of Public Administration, 57(4), 54-65.

Judge, K., Smith, J. \& Taylor-Gooby, P. (1983). Public Opinion and the Privatization of Welfare: Some Theoretical Implications. Journal of Social Policy, 12(04), 469.

Kingstone, P.R. (2003). Privatizing Telebrás: Brazilian Political Institutions and Policy Performance. Comparative Politics, 36(1), 21-40.

Kinnucan, M.T., Ferguson, M.R. \& Estabrook, L. (1998). Public Opinion toward User Fees in Public Libraries. The Library Quarterly, 68(2), 183-204.

Lecheler, S., de Vreese, C. \& Slothuus, R. (2009). Issue Importance as a Moderator of Framing Effects. Communication Research, 36(3), 400-425.

Legge, J.S., Jr. \& Rainey, H.G. (2003). Privatization and Public Opinion in Germany. Public Organization Review, 3(2), 127-149. 
Lindholst, A.C. \& Bogetoft, P. (2011). Managerial Challenges in Public Service Contracting: Lessons in Green-Space Management. Public Administration, 89(3), 1036-1062.

Lundqvist, L.J. (1989). The Literature on Privatization. Scandinavian Political Studies, 12(3), 271-277.

McAllister, I. \& Studlar, D.T. (1989). Popular versus Elite Views of Privatization: The Case of Britain. Journal of Public Policy, 9(2), 157-178.

Nelson, M.A. (1997). Municipal government approaches to service delivery: an analysis from a transactions cost perspective. Economic Inquiry, 35(1), 82-96.

Pollitt, C. \& Bouckaert, G. (2011). Comparative public management reform: An introduction to the key debates. In C. Pollitt, \& G. Bouckaert (Eds.). Public Management Reform. Comparative Analysis of New Public Management, Governance and the Neo-Weberian State. (pp. 1-25). Oxford: Oxford University Press.

Savas, E.S. (2000). Privatization and Public-Private Partnerships. New York: Chatham House Publishers.

Starr, P. (1988). The Meaning of Privatization. Yale Law and Policy Review, 6(1), 6-41.

Stubager, R., Holm, J., Smidstrup, M., \& Kramb, K. (2013). Danske valgere 1971-2011: En oversigt over udviklingen i valgernes holdninger $m v$. Aarhus: Institut for Statskundskab.

Tang, K. (1997). The case for the privatization of social welfare: Three decades of public opinion evidence from Great Britain and the United States. Scandinavia Journal of Social Welfare, 6, 34-43.

Thompson, L. (1997). Citizen Attitudes Toward Service Delivery Modes. Journal of Urban Affairs, 19(3), 291-302.

Thompson, L. \& Elling, R.C. (2000). Mapping Patterns of Support for Privatization in the Mass Public: The Case of Michigan. Public Administration Review, 60(4), 338-348.
Van de Walle, S. (2006). The impact of public service values on services of general interest reform debates. Public Management Review, 8(2), 183-205.

Warner, M.E. \& Hefetz, A. (2008). Managing Markets for Public Service: The Role of Mixed Public-Private Delivery of City Services. Public Administration Review, 68(1), 155-166. Vrangbæk, K., Petersen, O.H. \& Hjelmar, U. (2015). Is contracting out good or bad for employees? A systematic review of international experience. Review of Public Personnel Administration, 35(1), 3-23.

Walks, R.A. (2006). The causes of city - suburban political polarization? A Canadian case study. Annals of the Association of American Geographers, 96(2), 390-414.

--- (2008). Urban form, everyday life, and ideology: support for privatization in three Toronto neighbourhoods. Environment and Planning A, 40(2), 258-282.

\section{Noter}

1. Meningsmålinger gennemført af Megafon og Gallup i dagene omkring vedtagelsen af salget viste at store majoriteter på henholdsvis $68 \%$ og $80 \%$ af alle danskere var imod salget. I forhold til de politiske reaktioner skiftede blandt andet Dansk Folkeparti holdning til salget og underskrev ikke det endelige aktstykke om salget trods tidligere at have været en del af forligspartierne bag en børsintroduktion af DONG Energy og givet forhåndstilsagn til samtykke til indholdet af det endelige aktstykke. Flere ledende folketingspolitikere krævede endvidere en forlængelse af beslutningsprocessen for at belyse alternativer til salget yderligere, og sagen medførte umiddelbart, at Socialistisk Folkeparti gik ud af regeringskoalitionen med Socialdemokratiet og det Radikale Venstre. 